\title{
Overview of vibroacoustic isolators used in railway tracks
}

\author{
Cezary Kraśkiewicz ${ }^{1,}$, Wojciech Oleksiewicz $^{1}$, Monika Płudowska-Zagrajek ${ }^{1}$, and Cezary \\ Lipko $^{2}$ \\ ${ }^{1}$ Warsaw University of Technology, Faculty of Civil Engineering, Institute of Roads and Bridges, \\ 16 Lecha Kaczyńskiego Ave., 00-637 Warsaw, Poland \\ ${ }^{2}$ TINES Railway, TINES Capital Group SA, Ciepłownicza 23 Street, 31-574 Cracow, Poland
}

\begin{abstract}
The paper presents an overview of vibroacoustic isolators used in railway tracks to reduce negative effects from railway traffic. These include single components or their assemblies, with different material characteristics and location in the track structure due to track structure type (ballasted or ballastless track system). The reduction of negative effects relates mainly to the reduction of vibration and structure-borne noise. The practical solutions for railway structures include various components that perform different functions at the same time: vibroacoustic isolation and mechanical function to ensure safe and durable use of rail track (i.e. rail fastening systems, rail supporting structures). The main goals of this paper are systematization and description of basic material characteristics of vibroacoustic isolators applied sufficiently close to the place of vibration generation during the movement of rail vehicles.
\end{abstract}

\section{Introduction}

Rail track structure consists of many components, with different functions. One of them are vibroacoustic isolators used in railway tracks to reduce negative effects from railway traffic. These elements vary depending on material characteristics and location in the track structure due to track structure type (ballasted or ballastless track system).

In the classification according to [1] kinds of rail track superstructures it is appropriate to assume the main criterion linked with occurrence in a given structure of the ballast, as the main superstructure layer and its function of shaping the geometry of the track. When this feature is fulfilled, the track structure is qualified as ballasted track system (Fig. 1). Otherwise, it is qualified as ballastless track system (Fig. 2, 3). It is important for ballast layer to meet both of the above conditions, because ballast layer can occur in ballastless track system - in that case it serves different functions i.e.: drainage, thermal insulation or noise reduction.

\footnotetext{
*Corresponding author: c.kraskiewicz@,il.pw.edu.pl
} 


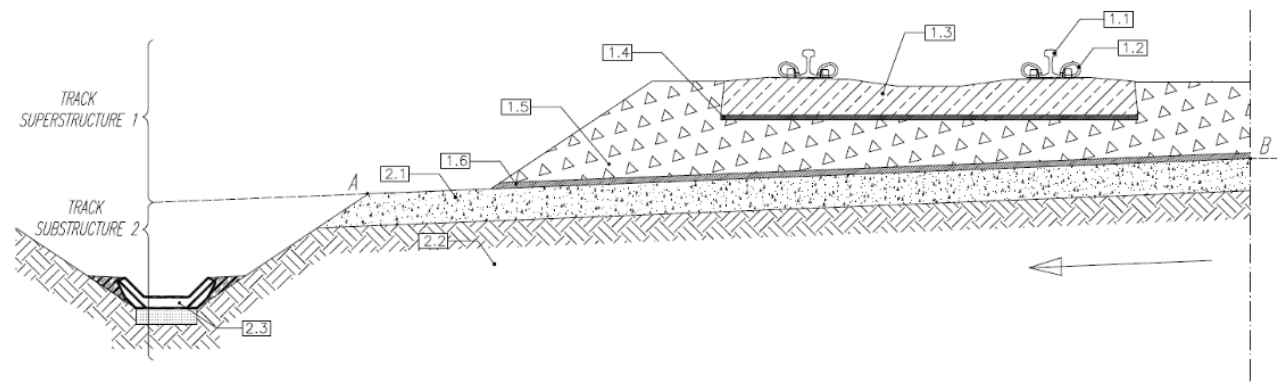

Fig. 1. Components of ballasted track system.

Key: Track superstructure (1): 1.1 - Vignole rail profile, 1.2 - rail fastening system (type SB or W14), 1.3 - rail sleeper, 1.4 - (option) under sleeper pad, 1.5 - ballast, 1.6 - (option) under-ballast mat. Track substructure (2): 2.1 - blanket layer, 2.2 - subgrade, 2.3 - surface drainage [1].

An example of ballastless track system on rail crossing in LC-L system is given in Fig. 2. The principle of rail fastening in ERS system, illustrated on Detail A, entitles of fixing rail in rail channel, where it is supported on continuous, resilient strip pad (polyurethane composite) and continuous layer of reis grout. After accurate horizontal and vertical positioning of the rail, resilient casting elastomer (adapted to the operating conditions and required vibration damping effectiveness) is applied.

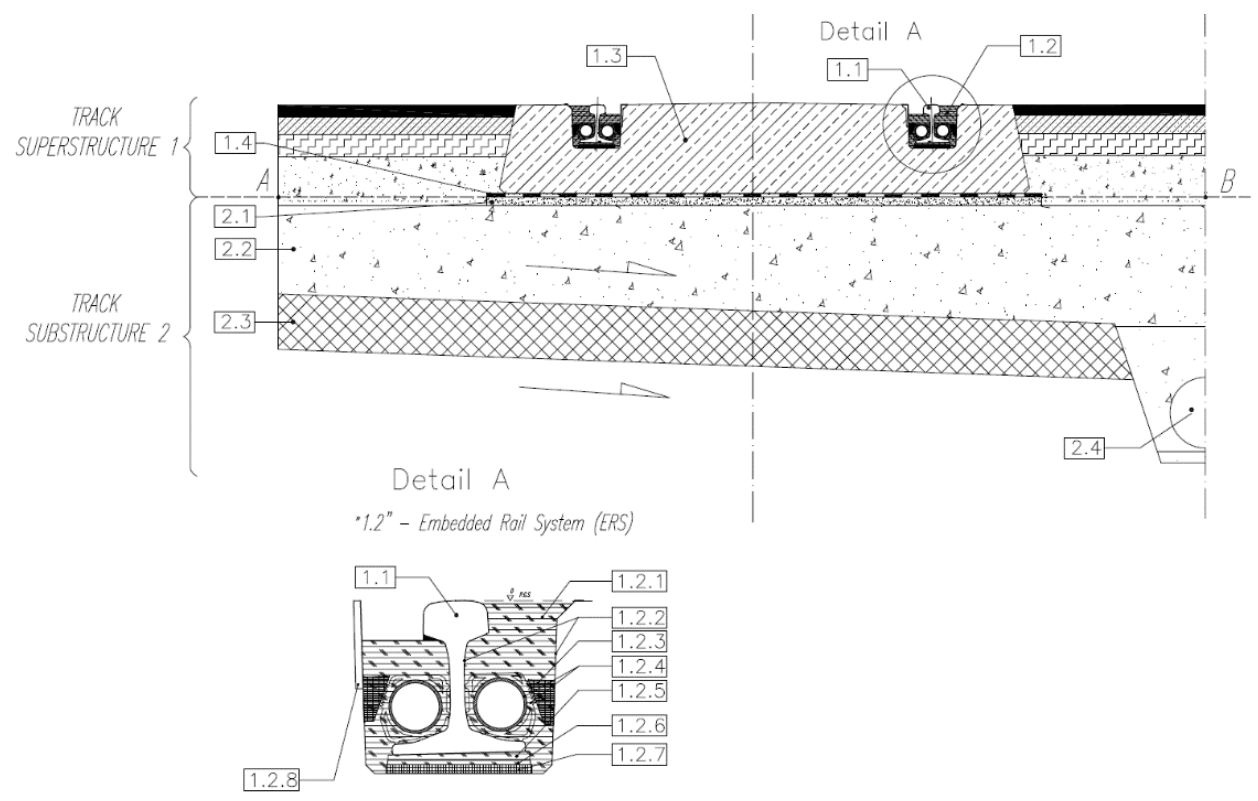

Fig. 2. Compounds of ballastless track system on railway crossing in Level Crossing-Length system (LC-L system) with integrated railway and road superstructure.

Key: Track structure (1): 1.1 - Vignole rail profile; 1.2 - rail fastening system - i.e. Embedded Rail System (ERS); 1.3 - concrete slab track; 1.4 - slab-track mat;

Track substructure (2): 2.1 - sand blinding layer; 2.2 - blanket layer; 2.3 - substructure - compacted and reinforced subsoil; 2.4 - drainage;

Detail A - 1.2 (Embedded Rail System) - key: 1.2.1 - resilient casting elastomer based on resins element of rail fixing and support, 1.2.2 - primer, 1.2.3 - wedges as a tool for horizontal alignment of the rail, 1.2.4 - material saving item, 1.2.5 - polymer inclination shims for providing inclined position of the rail, 1.2.6 - polymer shims as a tool for vertical leveling of the rail, 1.2.7 - resilient strip mat, 1.2.8 - continuous, steel reinforcement of inner edge of the rail channel [1]. 
The following figure (Fig. 3) shows a use of a ballastless track system in a tunnel on example of the Warsaw Metro Line II.

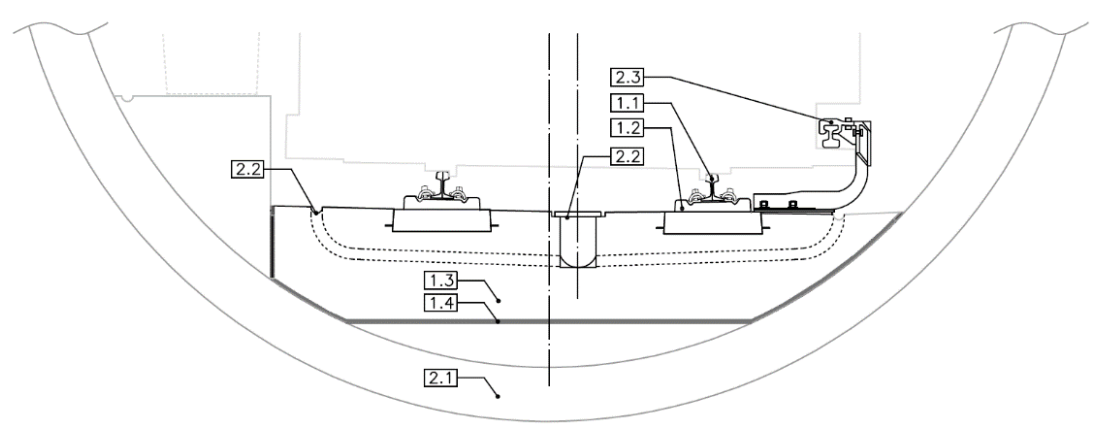

Fig. 3. Components of ballastless track system in a tunnel on example of the Warsaw Metro line II. Key: Track superstructure (1): 1.1 - Vignole rail profile type 49E1;1.2 - rail fastening system Embedded Blocks System (EBS); 1.3 - concrete track slab; 1.4 - slab-track mat. Track substructure (2): 2.1 - concrete inverted slab; 2.2 - surface drainage; 2.3 - conductor-rail [1]

\section{Application areas of vibroacoustic isolators in railway tracks}

The application areas of vibroacoustic isolators in railway tracks are given in Fig. 4.

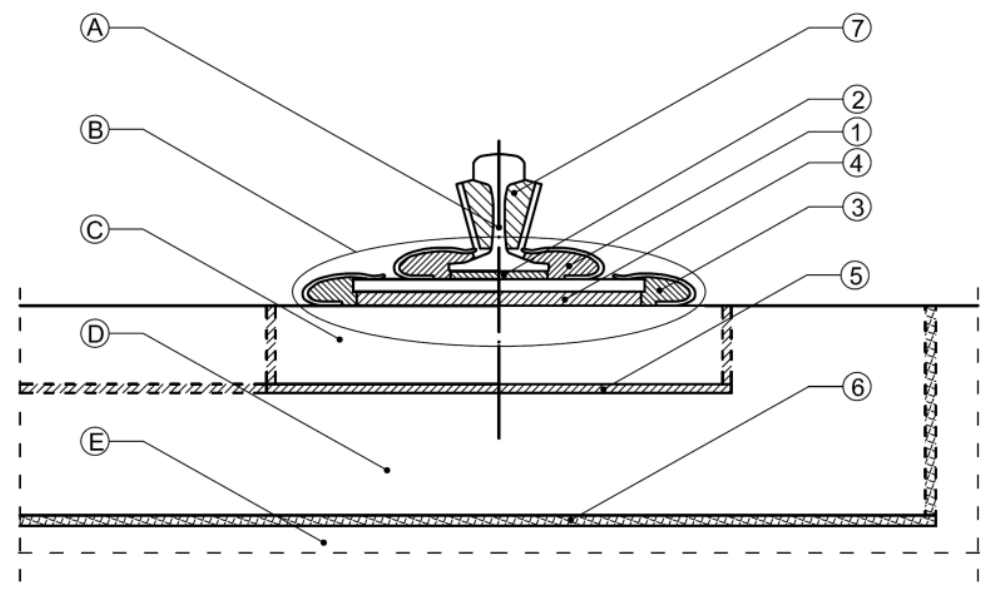

Fig. 4. Application areas of vibroacoustic isolators in railway tracks. Description of rail track components: A - Vignole rail; B - fastening system; C - rail supporting system (C.1 - - rail sleeper in ballasted track system or C.2. - rail supporting structure in ballastless track system); D.1. - ballast layer in ballasted track system or D.2. - concrete base plate in ballastless track system; E - track substructure.

The application areas of vibroacoustic isolators in railway tracks may include the following elements (Fig. 4):

- resilient fastening (fixing) of rail foot (1): resilient clamps or grouting;

- resilient fastening (supporting) of rail foot (2): rail pad, continuous rail pad, discrete or continuous grouting;

- resilient fixing in indirect rail fastening system (3): tension clamps, anchor bolts with compression spring; 
- resilient support of rail supporting structure in indirect rail fastening system (4): base plate pad, discrete grouting;

- resilient support or fixing of rail supporting structure (sleeper or block) (5): under sleeper pad, under block pad, grouting;

- resilient fixing and support of railway track (6): under-ballast mats or slab-track mats - which with rail track structure compose floating slab track system;

- filling gaps between fishplate and rail web (noise reduction) (7): grouting or rail web filler block.

\subsection{Resilient rail fastening systems}

In the entirety of the listed components of rail track structure rail fastening system demonstrates the greatest diversity of design solutions that constitute the basis for differing classifications [1]. This is particularly the case of a ballastless track structure, where resilient of load-bearing capability necessary for the proper functioning of the system must be provided by variously solved resilient elements of rail fastening system. The variety of possible design solutions is result of dynamic development of material engineering.

One of the basic classifications criterion of a rail fastening system is their continuity in the rail track. It is illustrated in Fig. 5, where two sorts of rail fastening systems are defined: discrete and continuous.

a)

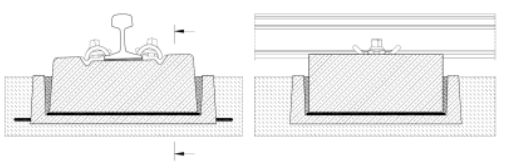

b)

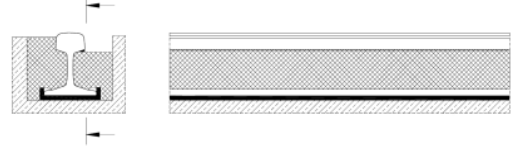

Fig. 5. Illustration principle of classification of rail fastening systems due to criterion of their continuity occurrence in rail track; a) discrete rail fastening (i.e. rail fastening in Embedded Blocks System - EBS); b) continuous rail fastening (i.e. Embedded Rail System - ERS) [1].

Another basic classification of rail fastening systems is classification due to criterion of the fixing rail with the rail supporting structure. The fastening system, where the rail is directly fixed to the supporting structure by anchors, bolts or screws is described as a direct rail fastening system (Fig. 6a, 6b). However, if the rail is fixed to the supporting structure with the usage of additional element (i.e. ribbed base plate), then these systems is described as indirect rail fastening system (Fig. 6c).

The term of rail fastening system used in standard [2] requires more detailed description of its two main functions specified in that standard as rail support and rail fixation.

The rail support system provides absorption of vertical loads and transfers them to a ballast layer (ballasted track system) or a substructure - a concrete base plate (ballastless track system). In the rail support the force vector (connected to the stiffness of rail supporting structure) acts downwards.

The elements of a supporting rail system (both continuous and discrete) are rail pads, resilient railfoot profiles, resilient elastomeric grout based on polyurethane reins and others, if included (i.e. ribbed base plate, elastic pad). The material features of a rail supporting system components act upon their functions: static and dynamic stiffness of support, protection against stray current and restraint against longitudinal rail displacements.

Rail fixing is the function of a rail fastening system to ensure:

- clamping force acting on a rail foot; 
- restraint against longitudinal rail displacements (effect of clamping force and friction coefficient);

- torsional resistance against rail rollover (effect of lateral shear resistance of anchor elements);

- electrical insulation between the rail and the supporting structure (sleeper, block or concrete slab) providing protection against stray current.

a)

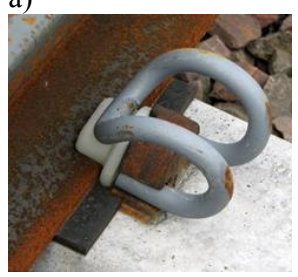

b)

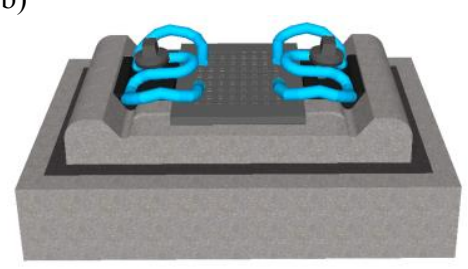

c)

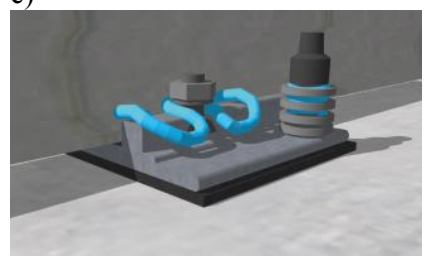

Fig. 6. Illustration principle of classification of rail fastening systems due to criterion of fixing rail with rail supporting structure: a) direct rail fastening system (SB fastening system), b) direct rail fastening system (embedded blocks system with tension clamps type Skl 14), c) indirect fastening system (ribbed base plate) [1].

The presented classification variants of rail types fastening systems, apart from the classical division on direct and indirect, following systems can be specified due to design solution and interconnectedness of rail supporting and fixing:

- discrete rail fastening system - discrete both rail support and rail fixing, i.e. Embedded Blocks System (EBS);

- continuous rail fastening system - continuous both rail support and rail fixing, i.e. Embedded Rail System (ERS);

- mixed rail fastening system - continuous rail support and discrete rail fixing, i.e. direct rail fastening to concrete slab with continuous grout - fig. 7).
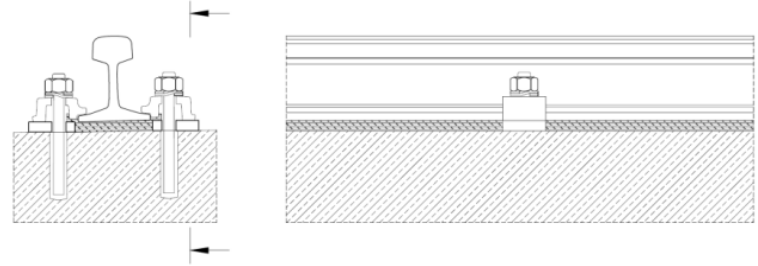

Fig. 7. Mixed rail fastening system (direct rail fastening to concrete slab) [1].

\subsection{Resilient support and fixing of rail supporting structure}

The Under Sleeper Pads (USP) are used in ballasted track systems (Fig.1) to reduce the dynamic effects from the rolling stock transferred through the rails, fastening system, rail supporting structure (sleepers or turnout bearers) to the ballast.

The Under Sleeper Pads are produced from elastomeric materials and showcase two variants due to the applied material:

- pads based on polyurethane in versions with closed or open pores;

- rubber pads (composites based on blends of natural rubber and/or synthetic rubber).

The Under Sleeper Pads are fixed to the bottom of the sleepers or turnout bearers and cover overall or partially (in under rail section) the bottom surface of the sleeper (Fig. 8).

Mounting of the Under Sleeper Pads takes place: 
- during the production of the sleepers/turnout bearers by placing the pad on the bottom surface of the sleeper, in concrete mixture;

- on finished sleepers/turnout bearers by sticking the pad by means of using fast hardening adhesive (i.e. epoxy glue).

The testing procedures for Under Sleeper Pads are given in standard [3], but it does not specify the required parameter values.

a)

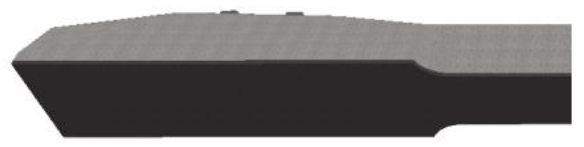

b)

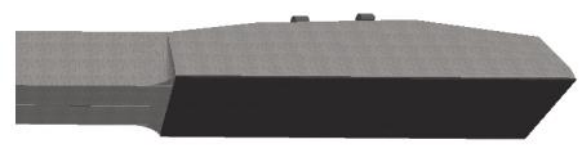

Fig. 8. Under Sleeper Pad: a) overall coverage the bottom surface of the sleeper; b) partial coverage the bottom surface of the sleeper (in the area of the main transmission of vertical pressure).

Details of the support block in EBS (Embedded Block System) and components of the rail fastening system are given in Fig. 9. The rail supporting structure in Embedded Block System is an example of floating slab track system, where a heavy support block is set at the resilient under-block pad. Significant vibration damping in EBS system is also attained due to elastic fixing of the support block in the socket by means of grouting, which serves as a support block coating.

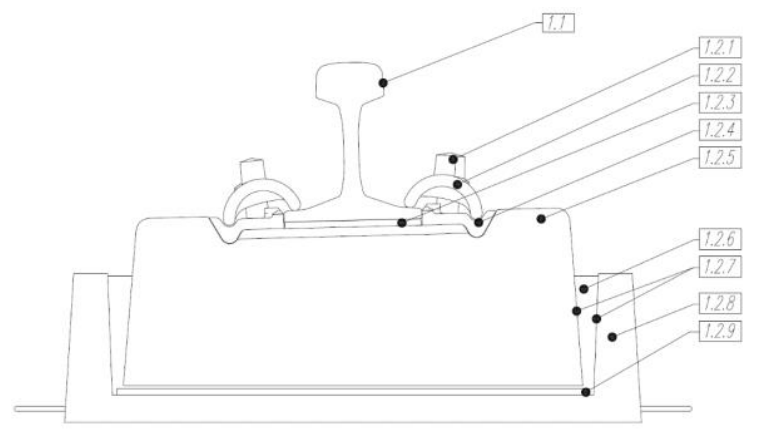

Fig. 9. Detail of support block in Embedded Block System (EBS) - Key: 1.1 - Vignole rail, 1.2.1 sleeper screw; 1.2.2 - tension clamp type Skl-14; 1.2.3 - rail pad (resilient rail support), 1.2.4 angled guide plate Wfp; 1.2.5 - reinforced concrete block; 1.2.6 - resilient compound; 1.2.7 adhesive material; 1.2.8 - prefabricated concrete tray or concrete slab; 1.2 .9 - resilient under block $\operatorname{pad}[1]$.

\subsection{Resilient support and fixing of rail track structure}

Resilient mats in railways are used for vibration isolation of railway tracks by means of reducing dynamic effects of rail traffic. The reduction relates mainly to vertical and transverse material vibration, but also to structure-borne noise [4, 5].

In a slab track system resilient mats are applied horizontally and vertically directly below and from the sides of the concrete track base plate (Fig. 11) to provide resilient support layer for railway track. The resulting floating slab track system is effective in mitigating vibrations, especially at low frequencies, and achieve a significant reduction in vibrations and structure-borne noise emissions at excitation frequencies above $\sqrt{2}$ times the tuning frequency $[6,7,8,9,10]$.

Resilient mats can be grouped into two categories, because of the range of applications in various types of railways track construction: 
- Under-Ballast Mats (UBM)/ Sub-Ballast Mats (SBM) - used in ballast railway track (Fig. 1); their two variants can be classified due to the main purpose of their use according to standard [11]:

a. used primarily for isolation from vibration,

b. used primarily for stress reduction in ballast $[12,13]$.

- Slab-Track Mats (STM) - used in ballastless railway track (applied under or from the sides of concrete track base plate - Fig. 11), with three variants of a slab support system according to standard [14]:

c. discrete support (steel springs or elastomeric pads) - Fig. 10,

d. linear support (strip mats) - Fig. 10,

e. continuous support (elastomeric mats) - Fig. 11.

Due to the applied materials and production technologies, resilient mats can be grouped into mats made of various kinds of elastomers (elastomeric mats) or mineral wool mats. Elastomeric mats can be divided into two groups:

- mats based on polyurethane in versions with closed or open pores;

- rubber mats (composites based on blends of natural rubber and/or synthetic rubber), whose resiliency is ensured by shape (channels, grooves or protrusions of different shape) and cross-sectional structure of the mat (density and pore volume).

The given examples of floating slab track systems (Fig. 10-11) are individual, customized solutions, they differ in terms of basic dimensions of components, as well as kinds of applied resilient elements. Characteristics of resilient mats important for vibration isolation and their test methods were given in standard $[11,14]$.

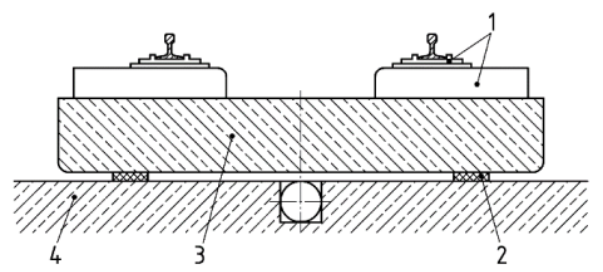

Fig. 10. Example of rail track structure in floating slab track system. Key: 1 - fastening system and support block, 2 - slab-track mat (discrete or linear support), 3 - concrete track base plate, 4 - tunnel invert slab with drainage pipe [15].

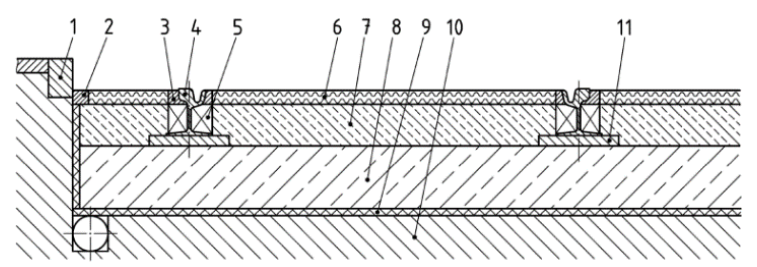

Fig. 11. Example of rail track structure in floating slab track system. Key: 1 - kerbstone, 2 - resilient joint, 3 - grouting, 4 - rail, 5 - rail web filler block, 6 - asphalt, 7 - concrete filling, 8 - reinforced concrete track base plate, 9 - resilient mat as continuous support, 10 - consolidated formation with drainage, 11 - resilient continuous strip [15].

\section{Conclusions}

Vibroacoustic isolators are components used to limit the negative effects (vibration and noise) generated by rail traffic on the track and are applied possibly close to the location of vibration generation during rail traffic (contact area of the wheel with the rail). 
Along with further advances in engineering and material engineering, as well as, increasing requirements for protecting surroundings of transport routes from negative transport effects, it can be concluded that vibroacoustic isolators will find an increasingly widespread use in rail track structure.

\section{References}

1. C. Kraśkiewicz, Współczesne budownictwo w badaniach młodych naukowców, Politechnika Gdańska, Wydział Inżynierii Lądowej i Środowiska, 126-140 (2017)

2. PN-EN 13481-5+A1:2017-04 Railway applications - Track - Performance requirements for fastening systems Part 5: Fastening systems for slab track with rail on the surface or rail embedded in a channel

3. PN-EN 16730:2016-08 Railway applications - Track - Concrete sleepers and bearers with under sleeper pads

4. M. Butorina, N. Minina, P. Ivanov, A. Petryaev, Procedia Engineering 189, 352-359 (2017)

5. P.Carels, Joint Baltic-Nordic Acoustic Meeting 2012, 1-16 (2012)

6. A. Zbiciak, C. Kraśkiewicz, C. Lipko, W. Oleksiewicz, IPICSE-2016, MATEC Web of Conferences 86, 01015 (2016)

7. J. Sołkowski, Materiały Konferencyjne, Stowarzyszenie Inżynierów i Techników Komunikacji Rzeczpospolitej Polskiej. Oddział w Krakowie 2(106), 159-175 (2015)

8. A. Zbiciak, C. Kraśkiewicz, W. Oleksiewicz, M. Płudowska-Zagrajek, C. Lipko, XXVI R-S-P Seminar 2017, Theoretical Foundation of Civil Engineering, MATEC Web of Conferences 117, 00090 (2017)

9. R. G. Wettschureck, M. Heim, S. Mühlbachler, Proceedings Inter-noise 97, 577-580 (1997)

10. R. G. Wettschureck, F. Breuer, M. Tecklenburg, H. Widmann, Rail Engineering International 4, 12-16 (1999)

11. DIN 45673-5:2010-08 Mechanical vibration. Resilient elements used in railway tracks. Part 5: Laboratory test procedures for under-ballast mats

12. S. K. Navaratnarajah, B. Indraratna, Journal of Geotechnical and Geoenvironmental Engineering, 143, 6 (2017)

13. S. K. Navaratnarajah, B. Indraratna, S. Nimbalkar, Procedia Engineering 143, 1108 1119 (2016)

14. DIN 45673-7:2010-08 Mechanical vibration - Resilient elements used in railway tracks - Part 7: Laboratory test procedures for resilient elements of floating slab track systems

15. DIN 45673-1:2010-08 Mechanical vibration. Resilient elements used in railway tracks. Part 1: Terms and definitions, classification, test procedures 